\title{
USE OF SOCIAL MEDIA FOR STRATEGIES TO IMPROVE THE INDONESIAN ECONOMY FOR THE SUSTAINABILITY OF MSMES
}

\author{
Rofif Satria Azraputra ${ }^{a}$, Maryani ${ }^{\mathrm{b}}$, Erwin Halim ${ }^{\mathrm{c}}$ \\ Information Systems School Study Program, Information Systems, Bina Nusantara University, \\ Kemanggisan, Palmerah, Jakarta, Indonesia \\ rofif.azraputra@binus.ac.id ${ }^{\mathrm{a}}$, yanie@binus.edu ${ }^{\mathrm{b}}$, erwinhalim@binus.ac.id ${ }^{\mathrm{c}}$
}

Received: July $17^{\text {th }}, 2020 /$ Revised: August $21^{\text {th }} 2020 /$ Accepted: September $18^{\text {th }}, 2020$

\begin{abstract}
Indonesia is currently entering the phase of this demographic bonus that must be used well. In the process of advancing micro, small and medium economic development, many Indonesians become small entrepreneurs selling products to others. The proportion of young people exceeds $25 \%$ of Indonesia's total population of around 250 million, plus 59.2 million Micro, Small and Medium Enterprises (MSMEs) units, contributing $61.41 \%$ of GDP. Indonesia is Indonesia's two main economic powers. However, even though the January 2016 data shows that the potential for Information and Communication Technology (ICT) infrastructure has reached around $90 \%$ of the population, and the mobile penetration rate of internet users exceeds $126 \%$, there are still $90 \%$ of MSMEs. The unit is still running in the offline domain. Reaching $51.8 \%$ of the total population of Indonesia. Although he can only hold information technology by hand, one of them is through social media. You can take advantage of social media such as Facebook, Instagram, and Twitter to sell goods. E-UMKM is an Android-based application designed to sell Indonesian MSME products online and has been integrated with the system. The steps that must be taken include data collection, MSME product certification, application development, socialization and delivery systems. This activity is expected to help MSME business players in selling their businesses online through social media.
\end{abstract}

Keywords: Social Media, MSME, e-UMKM, Utilization of Information Technology, e-business Strategy

\section{INTRODUCTION}

The term millennial is indeed familiar. The term comes from the millennial generation, coined by two American historians and writers William Strauss and Neil Howe in several of his books. Millennial generation or generation $\mathrm{Y}$ is also called my generation or echo wave. In determining the population of this generation, there is actually no specific demographic information. However, experts classify them according to the initial and final year. The Y generation classification was formed for people born between 1980 and 1990 or early 2000. In early 2016, Ericsson released 10 "Consumer Lab Trends" to predict various consumer needs. This Ericsson report is based on interviews with 4,000 respondents in 24 countries/regions around the world. Among these 10 trends, some of them pay special attention to the behavior of millennials. Ericsson shows in its report that technology products will follow the lifestyle of millennials. This is because changes in behavior change along with technological developments. Thomas Jul, President of Ericsson Indonesia, said: "New technological products will emerge to adapt to technological changes." During this year, Ericsson made several predictions. One of them is the Native Streaming behavior, which is growing in popularity. Time spent watching the video stream also tripled. This fact proves that the behavior of millennials cannot be separated from watching online videos.

The current millennial generation is known as the "no gadgets, no life" generation. In carrying out their daily activities, millennials always use advanced technology in the fields of education and work. 
Technical complexity is not only available on smartphones or other gadgets. Even today, trade is becoming more and more modern. Instant addicts do not waste the development of the non-cash transaction model, they prefer to spend money to get a certain experience rather than saving to add assets. Of course, millennials usually prefer traveling in Indonesia and traveling the world, rather than saving investment. However, the younger generation does not spend a lot of time surfing the Internet using smart devices. From there, they got a lot of information from all over the world.

The development of SMEs in Indonesia has always received special attention from many groups including the government. This is due to the large number of dominant business sectors, high levels of labor absorption, large contributions to Gross National Product (GNP) and their contribution to export value, the role of small and medium enterprises in the national economy and their contribution can be seen. It is considered strategic. Big traders opened the way for small traders to sell without having to make a large profit, thus allowing small traders to profit from selling goods. Such goods are widely used by small traders to sell goods from large traders. The US Institute of Global Entrepreneurship and Development (GEDI) released the Global Entrepreneurship Index 2017.

Indonesia ranks 90th in the world out of 137 countries/regions, and ranks 103th out of 132 countries/regions compared to 2016. One of Indonesia's improvements that is considered superior in the index is the effort to use the internet. In terms of sales, there are also various kinds of people who start marketing by walking around or opening booths in other places, but very few people use social media or information technology to make transactions. If you use social media in the best possible way, you can help MSME companies get new customers. Every social media has different services and functions. Of course, because of different functions and services, a strategy is needed to market the products we sell and win market competition there. The benefits of social media in everyday life are also very important for everyone (including communication) to seek information about what is happening in society. Currently there are several types of social media that are booming including WhatsApp, Instragam, Twitter, Line, Blackberry Messenger, Facebook, etc. Someone must have various motivations when using social media. Simply communicating with others, knowing the development of something, sharing information and following one of the current trends, namely using social media as a form of self-existence. People who want to be known to the public through social media usually use open social media such as Instagram, Facebook, Line or Twitter. Because through social media, this is where we can communicate freely and openly. This is because entrepreneurs are already using social media to promote their products. Android-based applications as a marketing platform for MSME products in foreign markets are a step forward to improve the Indonesian economy. The internet is one of the most important content in business, especially in marketing. Social media marketing is very important for business development, especially in today's digital era, because social media marketing is not only easy to use, but the cost of running a business through social media is also very cheap.

Unlike Facebook, Twitter's social media has another perspective. Each Twitter post has limited characters. The problem that may be faced by MSME entrepreneurs is a marketing strategy that does not use social media. The lack of marketing will have an impact on decreasing the sustainability of MSME business actors. The sustainability of the MSME business depends on the number of existing buying and selling transactions. This is due to the large number of Twitter user interactions that talk about the MSME business. Twitter users usually want to learn and try to be a hot topic product. Instagram introduces photos on social media which are the main theme in these interactions. Every photo posted on Instagram has a title or image caption that can describe the posted photo. This is of course very useful for MSME players to market their products. Instagram also has a hashtag function, which can combine all images in the hashtag category.

Instagram reports to followers, how many followers cause many interaction patterns on social media. The number of photos and hashtags and titles that match those photos can increase the number of existing followers, which can increase the amount of coverage. Of course, in terms of social media optimization, there are strategies to gain market share in social media. It is hoped that this service activity can help MSME players in maintaining their business continuity. The number of social media users is increasing every year. Not only users, various types of platforms on social media are also increasing. Social media is part of communication and sharing information in everyday life. This 
changes consumer behavior, which is a problem companies have to solve. With the advent of social media, companies' strategies and tools for interacting with customers have changed dramatically. Various social media platforms have become a natural part of a company's marketing strategy, especially for Small and Medium Enterprises (SMEs).

The era of the internet and smart phones (smart phones) has encouraged communication and human interaction in cyberspace without boundaries. Internet and smart phones are new tools in democracy or popular as a digital democracy. This tool helps the public to control, provide input and correct state administrators and public services. The Internet has also facilitated the dissemination of information online (online) or online, as well as in live broadcasts or video calls (video calls, video calls). In addition, it also promotes the circulation of science and technology through the mass media, periodicals and books that make it easier for anyone who wants to learn. Lectures and discussions can be conducted online to accelerate the exchange of knowledge and technology. Thanks to online media and social media, talents in various fields have been discovered. In general, social media provides companies with various advantages and opportunities as it helps attract new customers and maintain relationships with existing customers. In addition, social media can be used to increase collaboration with customers thereby accelerating innovation. According to industry social media reports, $86 \%$ of marketers believe that social media channels are an important part of their marketing plan. Social media allows companies to interact directly with end consumers at a relatively low cost and with higher efficiency, which is more effective than traditional communication tools. Companies are starting to use social media for various marketing purposes. Including branding, research, customer relationship management, service and promotion. For these various purposes, most companies use social media for branding.

\section{LITERATURE REVIEW}

\subsection{Micro, Small, and Medium Enterprises (MSMEs)}

Micro, Small, and Medium Enterprises (MSMEs) is a general term in the economic field and refers to productive economic enterprises owned by individuals or business entities in accordance with the standards stipulated in Law No. 20 of 2008. Micro business guidelines cover companies with net assets of IDR 50,000,000 (excluding buildings and land where the business is located). The maximum annual income from the sale of the micro business is IDR 300 million. Small business is an independent productive economic enterprise, whether owned by individuals or groups, not a branch of a large company. It is controlled and owned by medium-sized companies and is directly and indirectly included in it.

\section{MSMEs Criteria:}

\section{Micro Business}

The first entry criteria for MSMEs is a micro business. It is a company or company with a monthly net worth of around 50 million. Generally, for this type of business, the calculations do not include buildings and company-shaped assets as a place of business. In addition, micro businesses have certain characteristics. As if they have never carried out systematic financial management, it is difficult to get assistance from banks, the products sold are always changing, and the form of business is relatively small. Meanwhile, MSMEs that are included in the micro business standard are food stalls, chicken breeders, catfish breeders, hairdressers, meatballs and similar businesses.

\section{Small Business}

Small businesses have also become a standard for MSME business entities. A small business is a business that is managed by a person but is not classified as a business entity. Companies classified as small businesses typically have an annual wealth of less than 300 million. This is a perfectly calculated net asset. Small businesses also have certain characteristics. This means, because there is no bookkeeping system, there are difficulties in expanding the business scale, non-import and export businesses, and limited capital. Examples include small industry, cooperatives, small markets, convenience stores, etc. 


\section{Medium Enterprises}

If the net profit or assets of the company reach 500 million US dollars per month, then the business entity can be called a medium-sized company. However, as with other business standards, assets of this type (such as land and buildings) are not included in the calculation as a place of business. In addition, workers in companies that meet medium-sized enterprise standards usually receive health and employment insurance. For companies themselves, at least they must have a NPWP, neighbor's license and other legality. Examples of medium-sized companies are plantations, import and export trade, shipping, etc.

Characteristics of MSMEs:

1. Business locations can move around instead of staying in one place.

2. The types of goods sold can change at any time, there is no strict SOP to regulate them.

3. Simple financial management is sometimes still personal finances and company finances.

4. Most of them have no commercial legitimacy.

5. There is no strict and systematic system to regulate human resource problems in business entities.

\subsection{Gross National Product (GNP)}

Gross National Product (GNP) is an estimate of the total value of all end products and services produced by residents of a country in a given time period. GNP is usually calculated as the sum of personal consumption expenditure, private domestic investment, government expenditure, net exports, and any income that residents derive from foreign investment minus the amount of income foreigners earn in the domestic economy. Net exports are the difference between a country's exports minus imports of goods and services. The difference between Gross National Product (GNP) and Gross Domestic Product (GDP) is a closely related concept. The main difference between comes from the fact that there may be companies producing goods domestically by foreign residents, and residents of this country in the world. Companies that produce goods. And return the income to the resident's family. For example, there are many foreign companies that produce goods and services in the United States and transfer the earned income to their residents. So are many American companies. Producing goods and services outside the United States. And bring benefits to the US population.

\subsection{Social Media}

Social media is online media where users can easily participate, interact, share, and create content on blogs, social networks, Wiki, forums and cyberspace without being limited by time and space. Blogs, social networks and Wiki are the most common forms of social media used by people all over the world. Andreas Kaplan and Michael Haenlein define social media as "a collection of Internet-based applications built on Web 2.0 ideology and technology that can create and exchange user-generated content". Social media categorizes technology based on various forms of technology, such as magazines, Internet forums, blogs, social blogs, Weibo, Wiki, podcasts, photos or images, videos, ratings, and social bookmarking.

Characteristics of Social Media:

1. The information conveyed is not only addressed to one person, but also for a wider range. For example, messages sent via SMS or the Internet.

2. Messages sent freely or unnecessarily through the gatekeeper.

3. The message is often delivered faster than other media.

4. The recipient of the message determines the interaction time.

Social Media Functions:

1. Social Interactions

Social interaction is a variety of social relationships related to the relationship between individuals and individuals, individuals and groups, as well as groups and groups.

\section{Personal Branding}

Personal branding is a way to market yourself or your image.

\section{Communication Media}


Social media can be used as a medium of communication or as a place to build relationships between users. Because social media has global influence, users at the same level can communicate over long distances.

\subsection{Gross Domestic Product (GDP)}

Gross Domestic Product (GDP) is the market value of all goods and services produced by a country in a certain period of time. Nominal GDP refers to the value of GDP and is not affected by prices. At the same time, real GDP $\leftarrow$ (or GDP calculated at constant prices) $\rightarrow$ corrects the nominal GDP value by incorporating the price effect. Generally, low unemployment and an increase in public wage income are used as evaluation factors to assess the health of a country's economy. This is based on the high demand for labor from all levels of society in meeting the increasing demand for production due to economic growth. According to Ricky W. Griffin, nominal GDP will not be affected and inflation is not taken into account, while actual GDP does take into account existing inflation. In nominal GDP, the value of goods and services produced in a certain period (annually or quarterly) is calculated based on current prices.

\subsection{Benefits of Social Media}

What are the benefits of social media? Why do people now use social media so often? So let's take a look at some of the benefits of social media:

\section{Social Media Is Used To Socialize}

Social media is used to socialize between individuals and groups. If we want to chat with distant relatives, we can do it through existing social media. Such social activities can be done anytime, anywhere, and there is no time limit. But it depends on our internet connection.

\section{Social Media Can Also Find New Friends}

Social media is not only used for social interaction, but we can also make new friends. This is the benefit of social media, very interesting, and this we can do in an interesting way, especially for young people today. Isn't that interesting? We can also build relationships well.

\section{Social Media Is Also An Entertainer}

Sometimes if we are unhappy and bored with the piling up work, we can use social media to entertain ourselves. We can also find interesting things on social media, such as writing news on blogs and watching YouTube that can get rid of our boredom.

\section{Social Media Can Also Be Used To Make Money}

Sometimes if we are unhappy and bored with the piling up work, we can use social media to entertain ourselves. We can also find interesting things on social media, such as writing news on blogs and watching YouTube that can get rid of our boredom.

\section{METHODOLOGY}

The method used in this research is the process of implementing community service activities. The activities recommended in the implementation of the service are: 

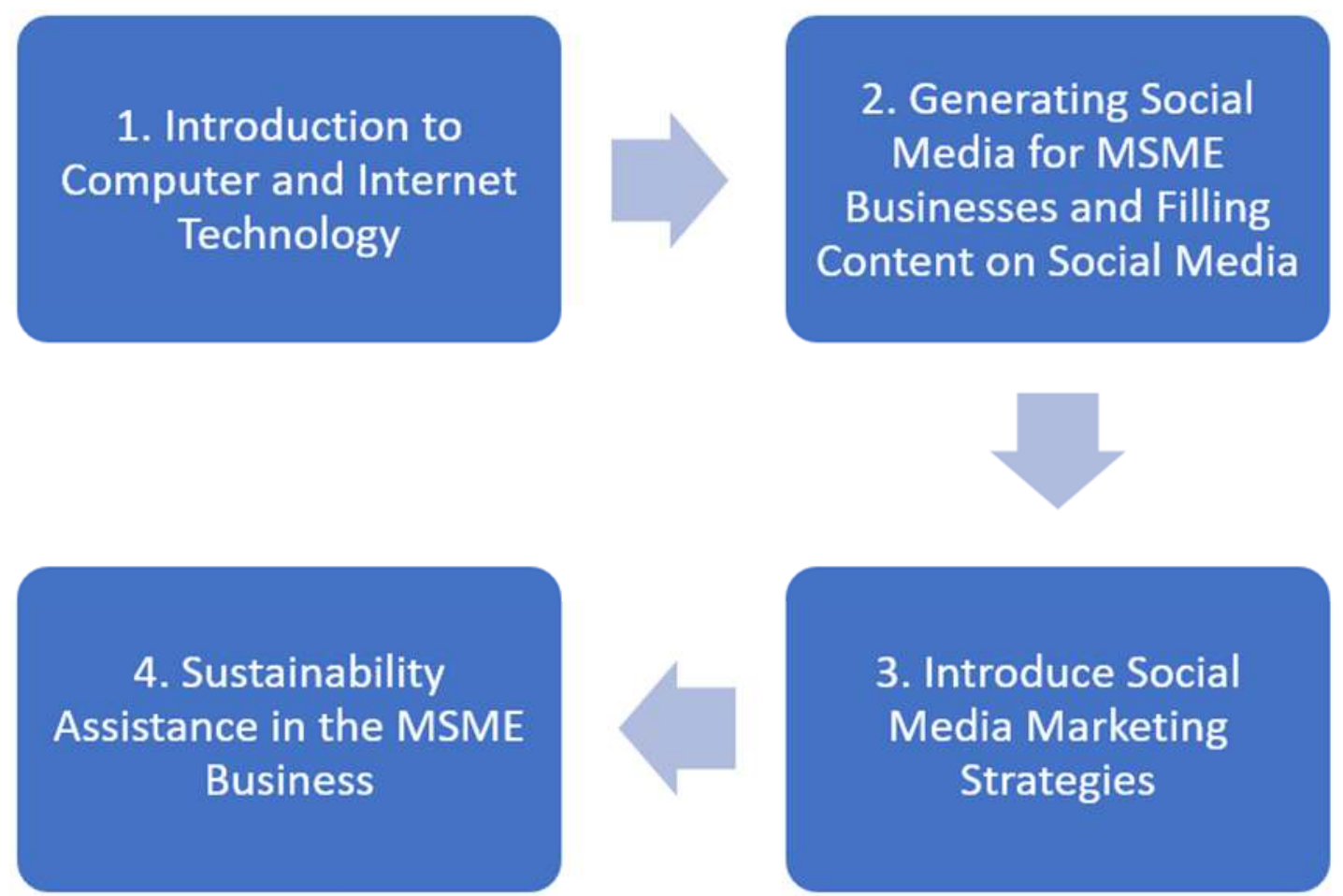

Figure 1 The process of implementing community service activities

This service activity has 4 materials to be sent, as shown in Figure 1. This activity is divided into 4 materials, so that you can receive the overall use of information technology. (1) Introduction to Computer and Internet Technology. MSME is expected to be able to operate computer technology and become more familiar with the Internet. This session will also introduce the digital economy using the Internet. (2) Creating social media for MSME businesses and filling content on social media. When creating social media, we will guide how to create social media accounts for MSME businesses, because company accounts are different from personal accounts on social media. (3) Introducing marketing strategies through social media. Marketing requires strategy. This strategy on social media is successful, allowing goods and services provided by MSME traders to enter the wider community. In addition, this strategy is needed to capture market share in social media. (4) Sustainability assistance in the MSME business. A strategy on social media is not enough, because it needs help so that the business can run simultaneously. This assistance will explain the maintenance strategies in the MSME business.

After formulating the process of implementing community service activities, now there is a qualitative description method. The descriptive method is a problem-solving procedure that conducts research by describing the object of research or the state of the object, whether it is a person, institution, society, or other people currently based on visible light or other objects. Qualitative methods tend to use descriptive and analytic methods. This method emphasizes process and meaning (thematic perspective). At the initial and final appointments, participants completed a survey of Williams (2006) perceptions of social capital. The purpose of this study is to determine the impact of the use of social media, creativity and venture capital on the sustainability of MSMEs business in Jakarta in the millennium era.

\section{Research Sites}

This research was conducted in Jakarta.

\section{Research Objectives}

The research subjects were all Binus University students aged 17 to 24 who had been promoted on social media. 


\section{Data Source}

a. Primary Data

The data is obtained directly from the answers to all research questions posed by students.

b. Secondary Data

Secondary data of this research includes literature related to business promotion and social media.

\section{Methods and Data Collection}

The method I use is a questionnaire. Research questionnaires will be distributed to the online questionnaire for Binus University students.

\section{RESULTS AND DISCUSSION}

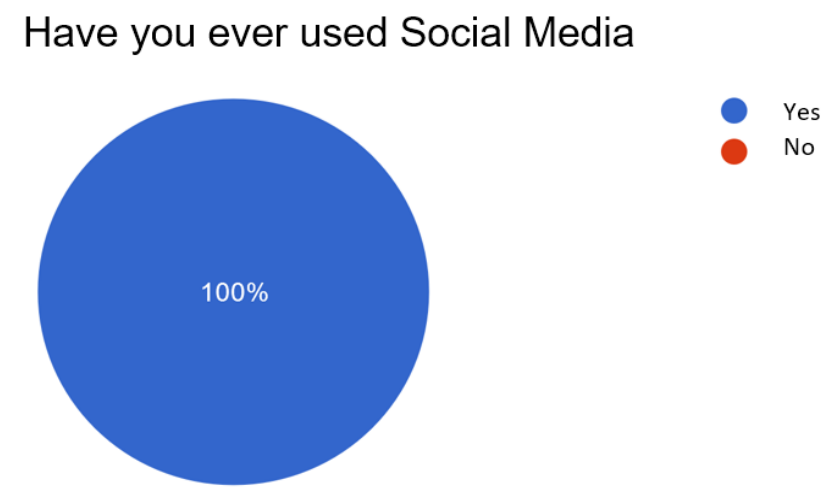

Community service activities are arranged and held in two meetings with different participants. The meeting lasts 2 hours, and the time allocated for each material is 30 minutes. It is hoped that all participants will bring communication tools in the form of smartphones, have an internet connection and register personal e-mails on their respective smartphones. In the discussion at the beginning of this service activity, the participants still did not know what kind of business they would be in. We help attendees get ideas on how to create a new business.

Based on the results of the questionnaire survey that you conducted with Bina Nusantara UMKM players, it appears that this study will survey 39 MSME respondents among all students. Of the 40 research questionnaires that were returned, all of the questionnaires met the requirements and could be analyzed, and those that could be analyzed were 40 questionnaires. The results of this study begin with everyone who owns social media. From the results of the data created, 100\% answered "yes". Because people really like social media, not without social media. This is a pie chart.

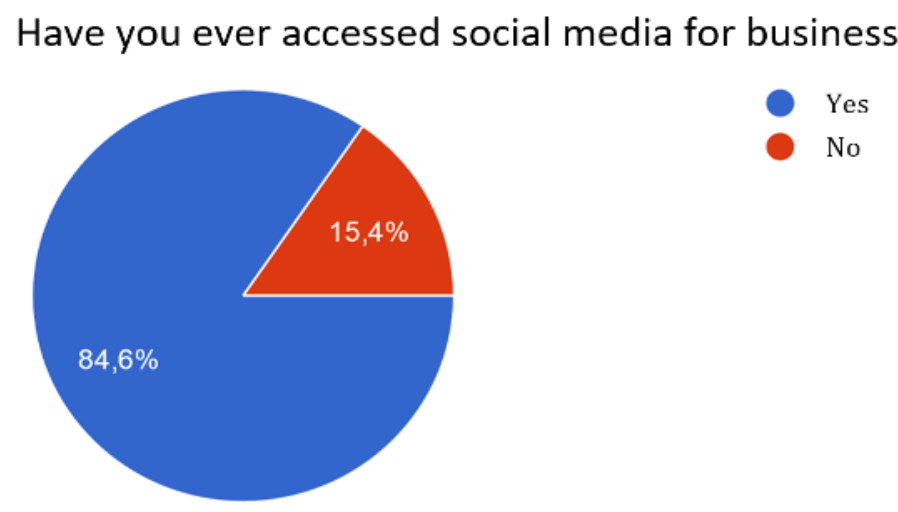


In today's COVID-19 pandemic, social media is the platform most visited by everyone. In addition, from young to old, all people can easily access social media. Therefore, by carrying out more complex promotions on social media, even with a shorter application period, the promotional results have not increased significantly, and certainly can increase marketing. My data result for social media is Instagram which accounts for $92.3 \%$. Because it can be seen from the Instagram chart which is the most interesting compared to the others.

Furthermore, we see that respondents have social media at the company. From the data I got, $84.6 \%$ answered "yes". Because people prefer Business social media rather than social media just chatting, watching movies, etc.

Now according to my data, many people do business on social media. Its business is commodities (goods), accounting for $64.1 \%$, food business $51.3 \%$, clothing business $38.5 \%$. Therefore, the commodity business is the most popular.

In addition, people want to know new product information on social media, especially from all over Indonesia. But there are also those who don't want to know about new products, from the data that I created, there are those who "agree" and "strongly agree" $43.6 \%$.

\section{What businesses use social media}

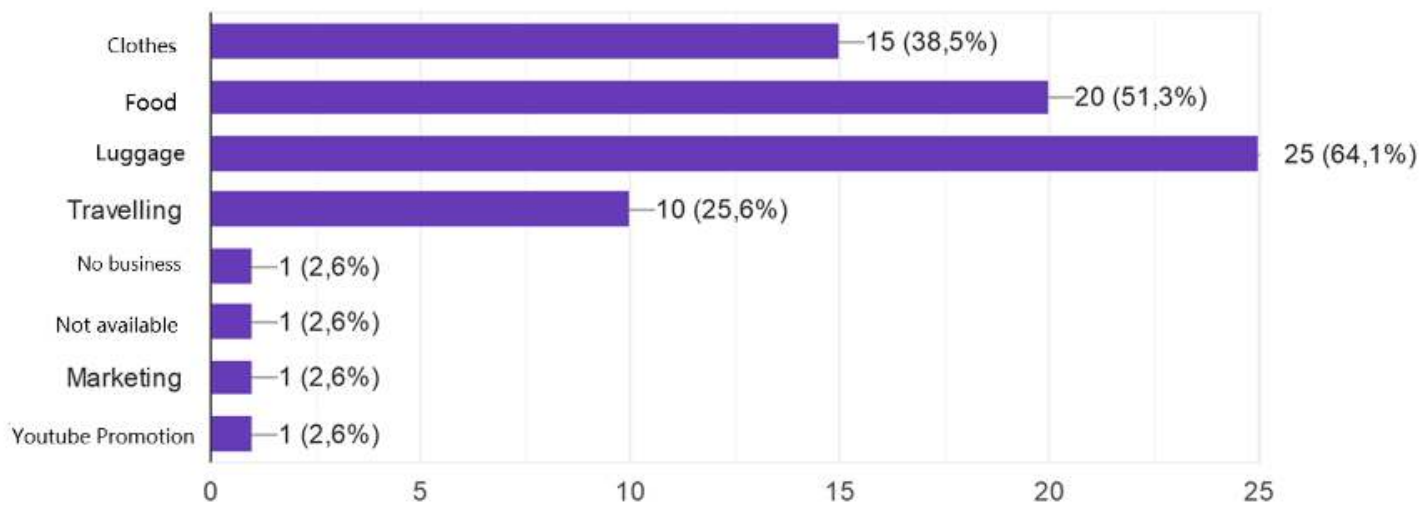

\section{Social Media that you use}

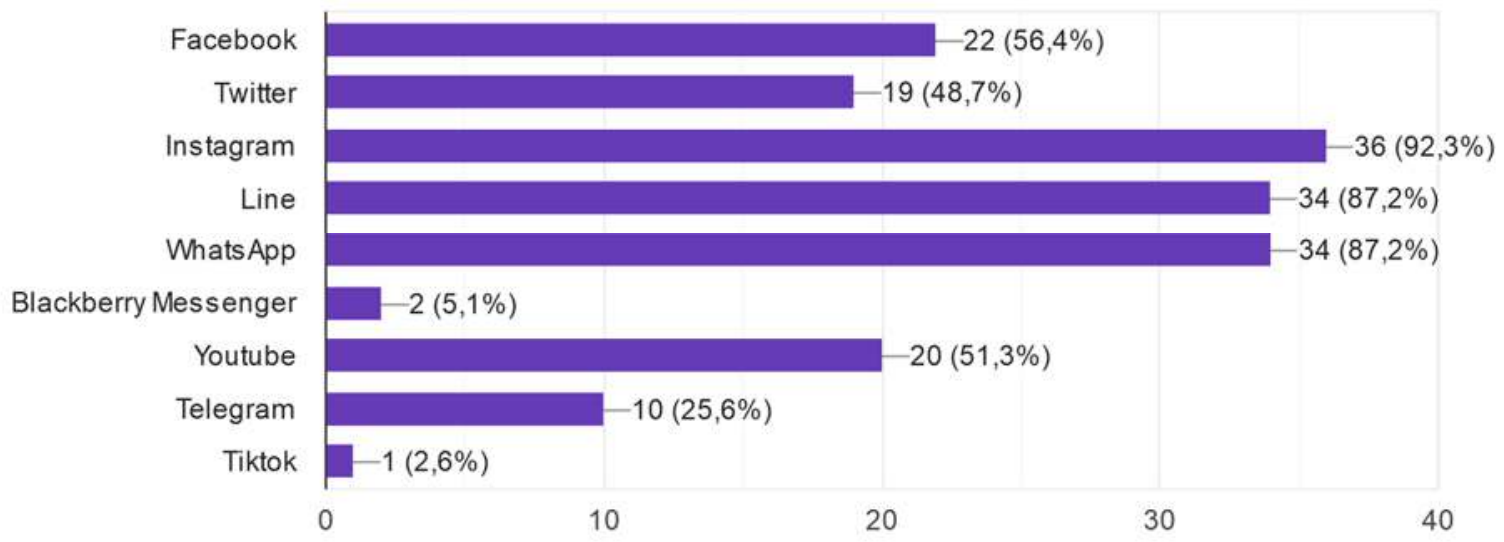




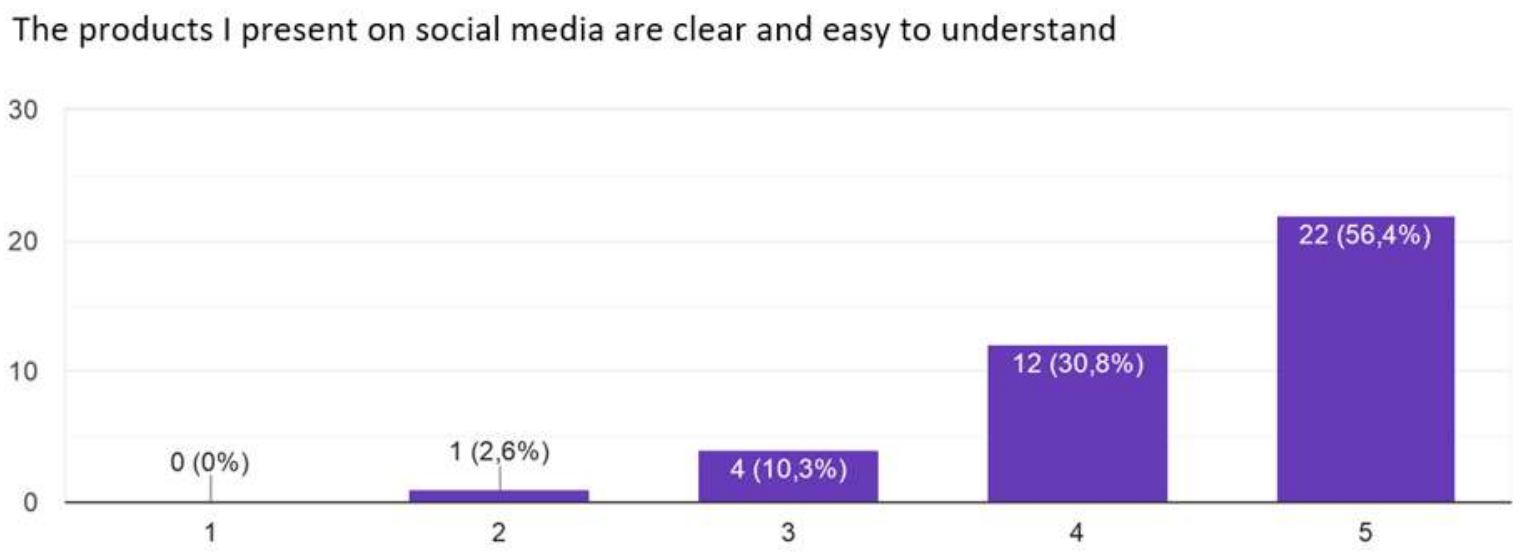

I always inform every new product on social media

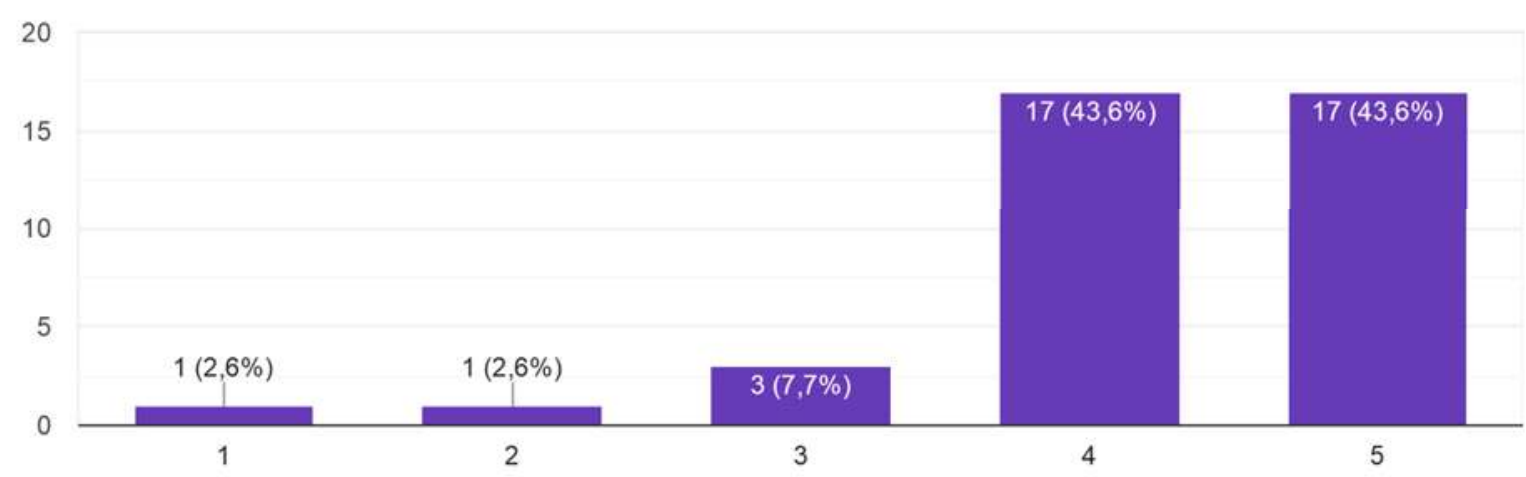

After we find out about new products through social media, these new products begin to be explained/communicated to social media so that they are easy to understand. According to the data I got, $56.4 \%$ of people answered "totally agree". Because the public/respondents will not know about new products on social media. So, people vote "totally agree".

In addition, these products will present interesting and innovative content. Based on the data I did,

\section{I always deliver products on social media with interesting and innovative content}

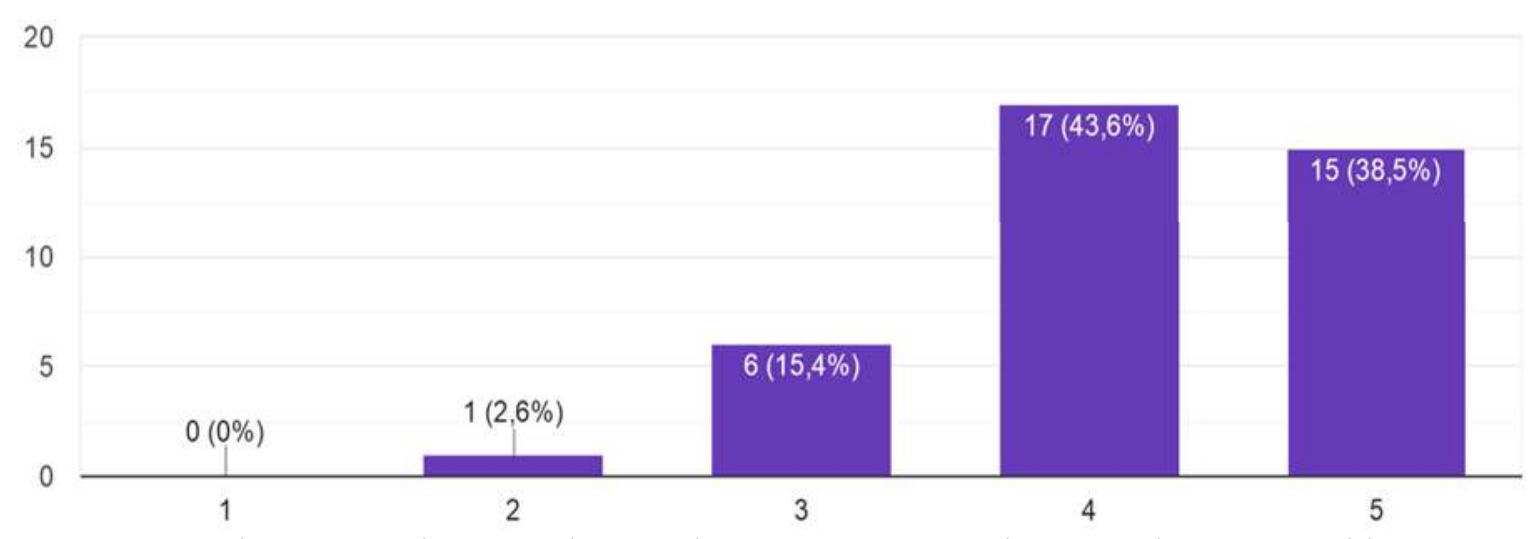

$43.6 \%$ answered "agree" and answered "strongly agree" $=38.5 \%$. The respondent answered because there was no strong agreement. Therefore the answer above the other answers is "agree" 
Currently, many people don't know the product we want, so today's traders want to build a famous brand so that people can understand the brand. For data, $43.6 \%$ answered "totally agree".

\section{Promotion on social networks makes the brand of a product famous}

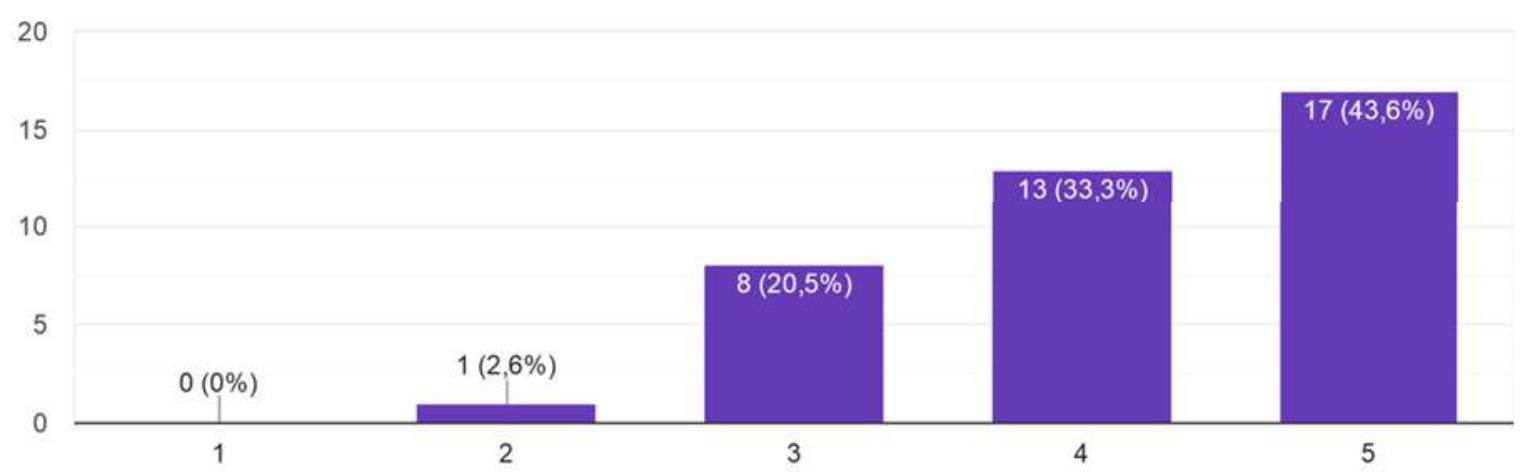

In addition, merchants will exchange ideas with other customers so that customers like the product they want and the products they buy. 35.9\% of the data answered "agree". Because people have more opportunities to chat with customers than to buy right away, and suddenly, their consumption isn't what they expected. Because of this, more people answered "agree".

\section{I always exchange ideas with other customers to advance the products I market}

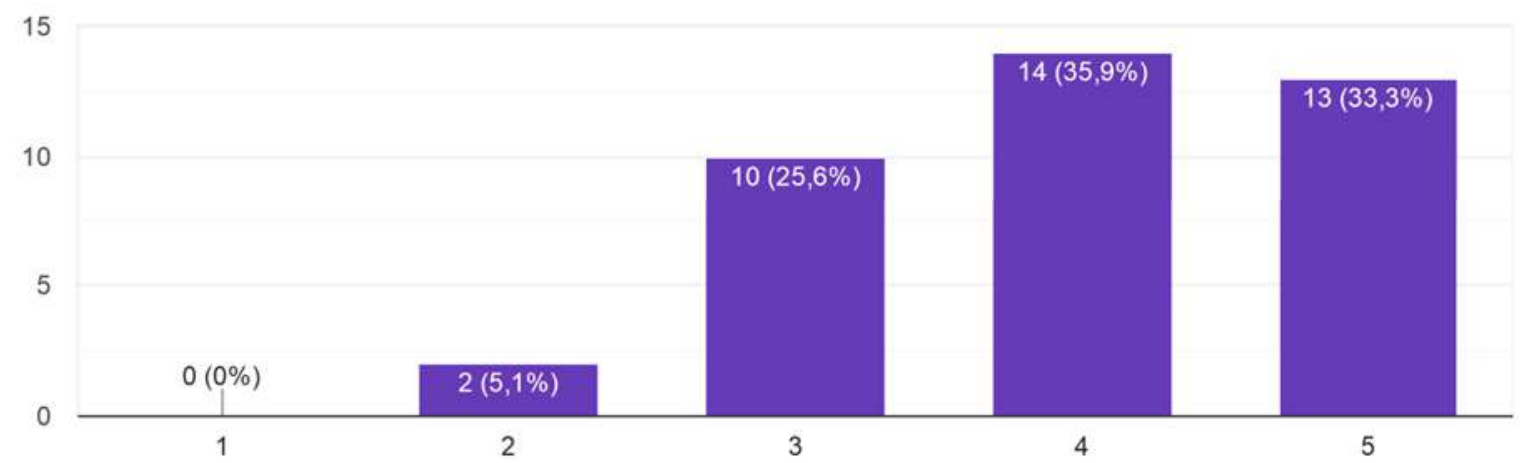

In addition, before notifying customers, he collaborated with other entrepreneurs to increase product sales on social media. By answering "agree", the data is $51.3 \%$. Therefore, merchant sales will be stronger. Therefore, the person who answered the most was "agreed".

\section{I work with other entrepreneurs to increase product sales on social media}

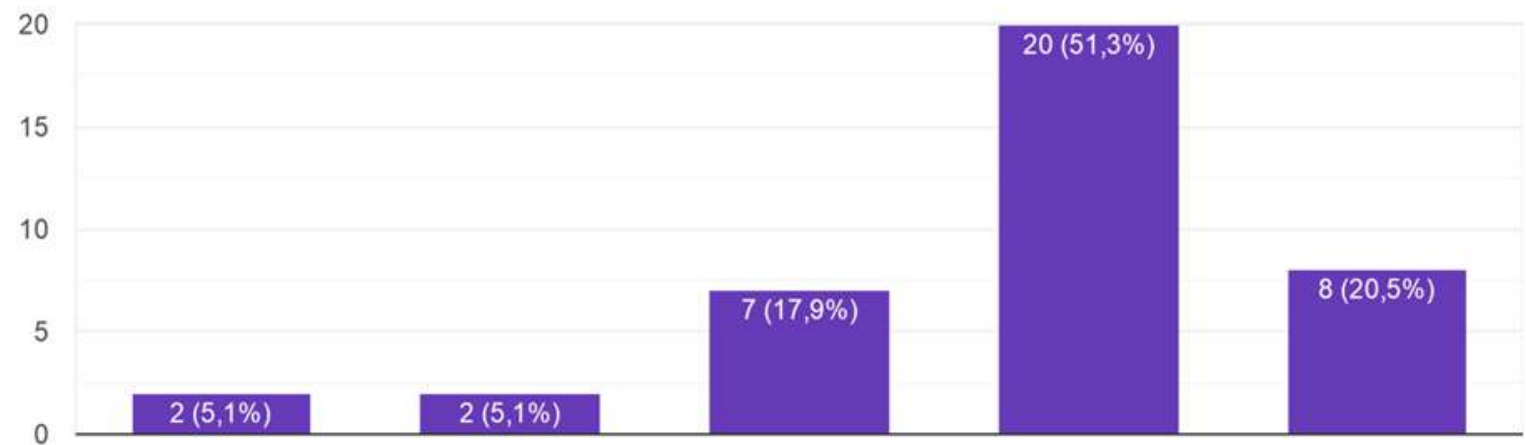


After consulting with other entrepreneurs, traders will be provided with high quality products that do not fake consumers. The data is $53.8 \%$, and the answer is "totally agree". The reason is, the products provided must be standard, not KW. Therefore, the number of people who answered "strongly agree" was the largest.

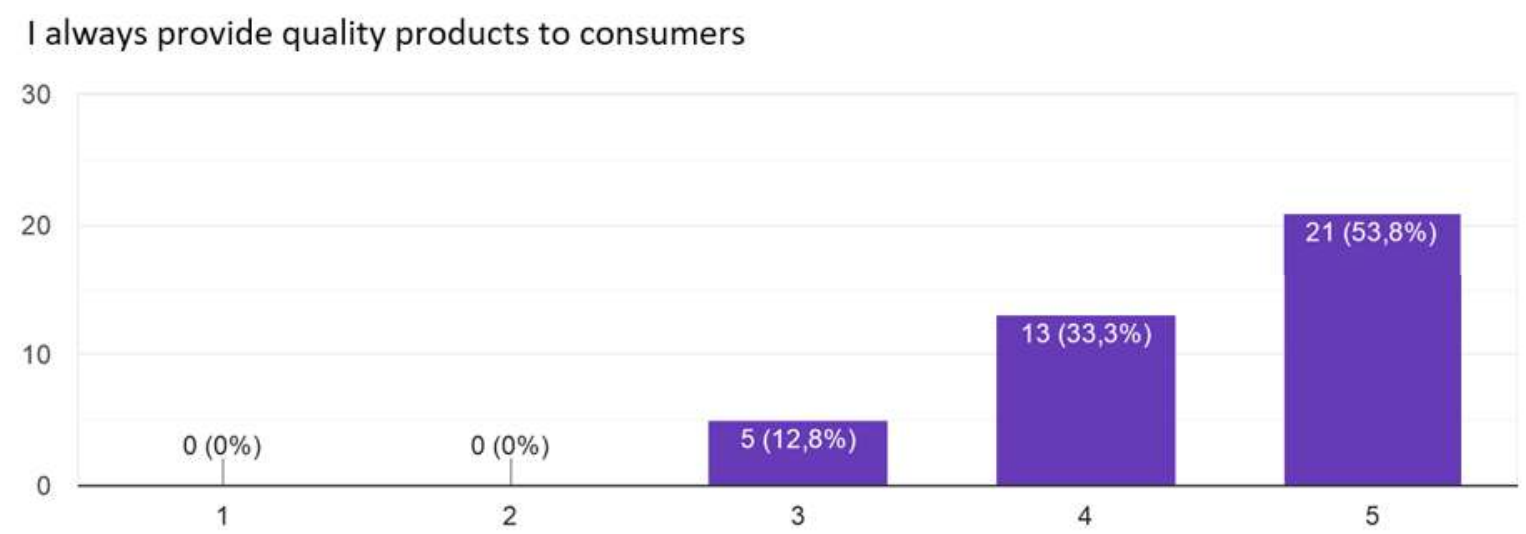

After providing quality products, we now see the production costs using social media which are relatively cheap compared to other promotional media. By answering "agree" and "strongly agree", data accounted for $41 \%$. Because people prefer cheap and affordable products on social media over very expensive products.

\section{Promotion costs using social networks are relatively cheaper than other promotional media}

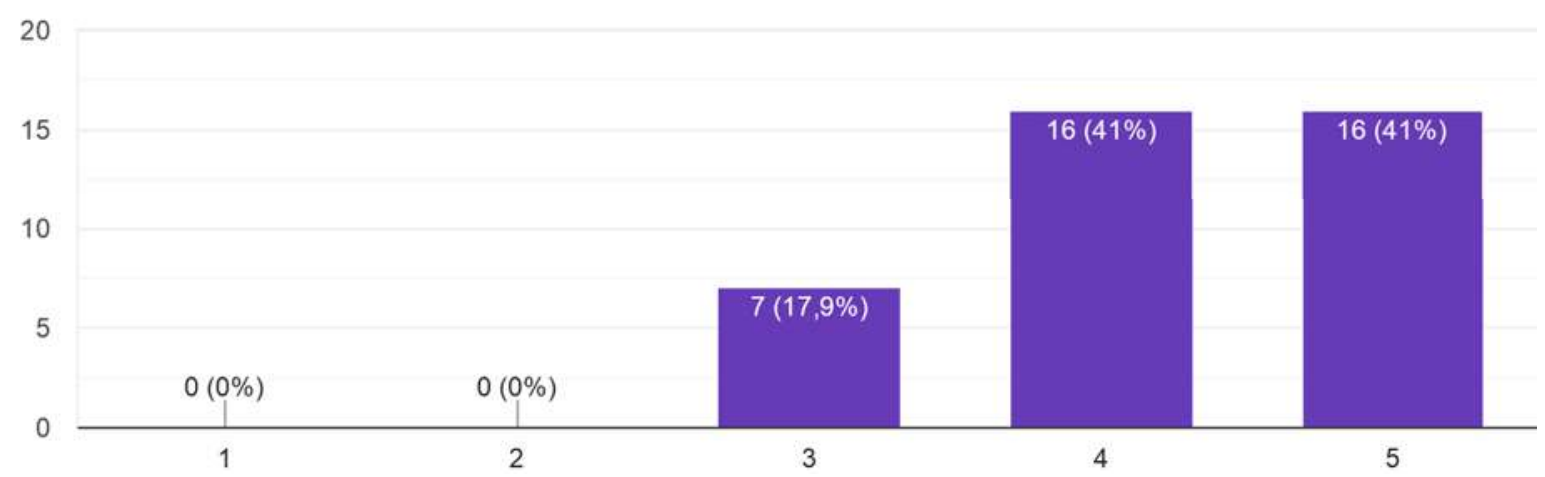

In addition, if we use hashtags (\#) to facilitate product promotion, we will agree, because in this data the answer to "totally agree" is $52.5 \%$. So if we use good hashtags, that's great.

The hashtag (\#) feature on social networks makes it easy for merchants to promote their products

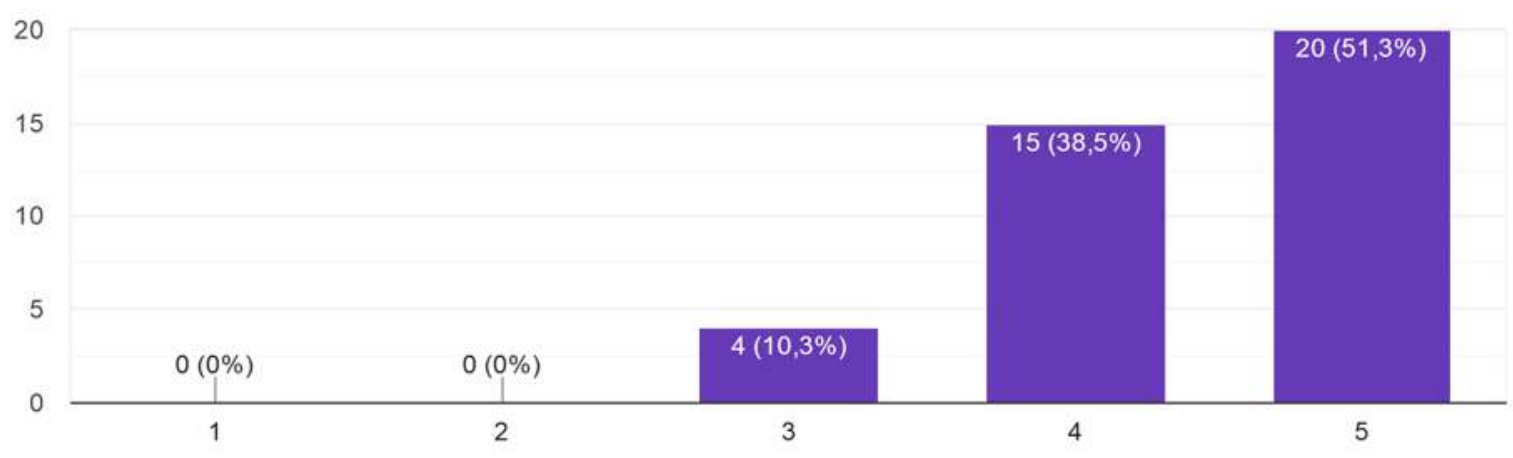


Later, after people get the product and pay, they usually receive a response from the customer. According to the data, $42.5 \%$ answered "strongly agree" and $32.5 \%$ answered "agree". Thus the highest ratio is $42.5 \%$.

After promoting the product on social networks the merchant receives regular feedback messages from customers

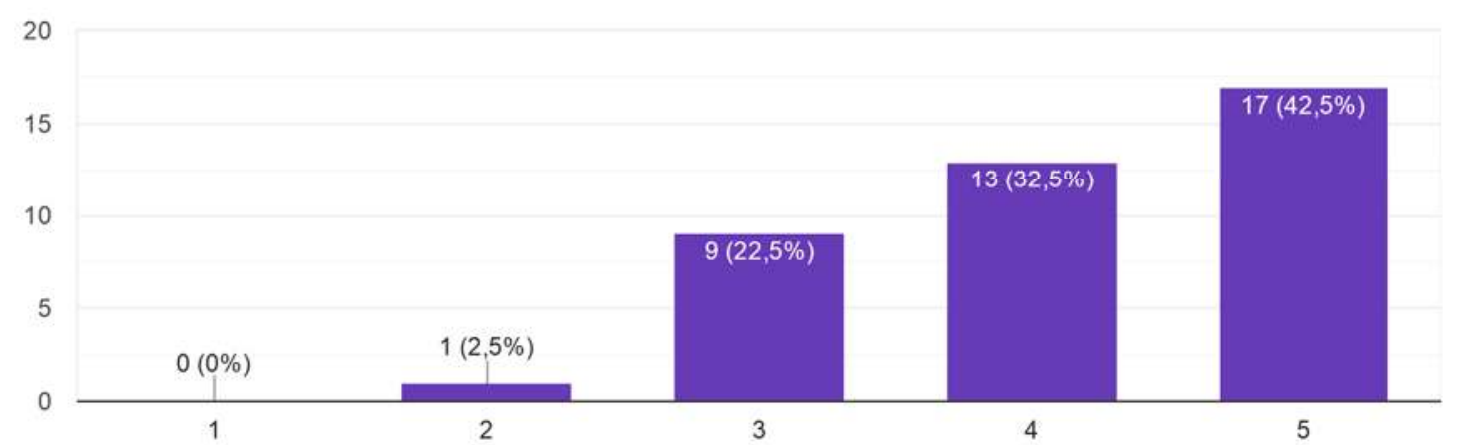

Everyone, when they see a good product and an interesting product, buy it right away and their following will increase. This is a graph. The most "agree" is $45 \%$. Because the more products you see, the more followers. Therefore, the most satisfactory answer was the percentage "strongly agree" at $35 \%$.

After that, we focused on product promotion on social media to get sales. According to my data, the

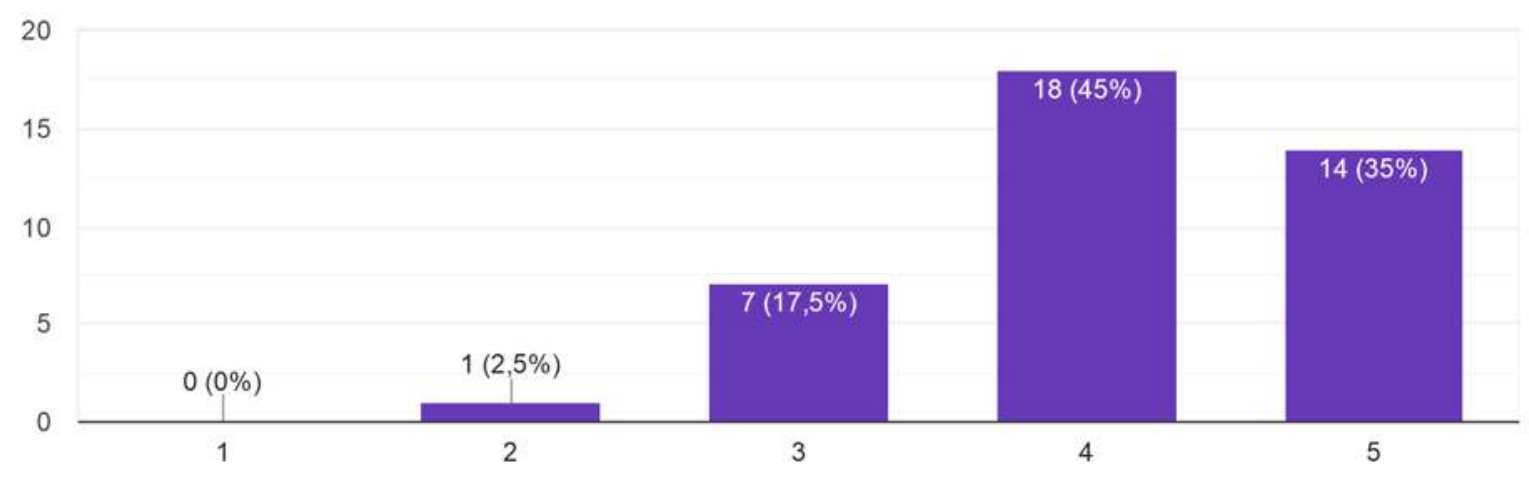

After promoting products on social networks the number of followers (followers) increases number of people who answered the most was $40 \%$, and the number of people who strongly agreed was $35 \%$.

\section{Promoting products on social networks increases sales volume}

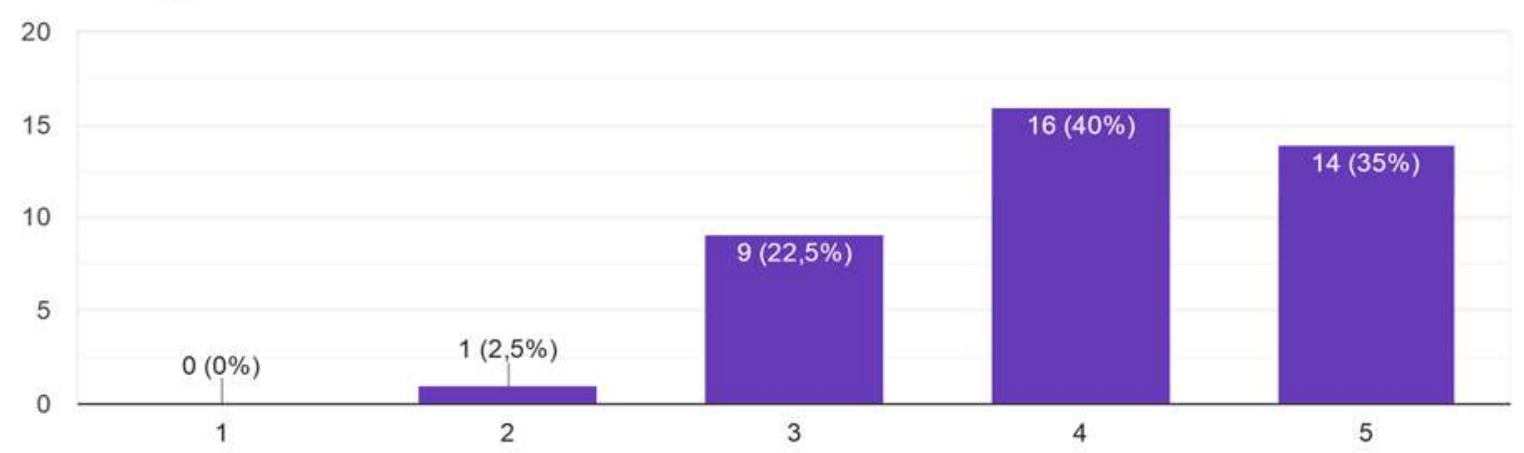


People who promote social media products by increasing business profits are good people. Because operating profit is better than others. Therefore, the data from the short-term chart to the highest chart is $47.5 \%$ (totally agree); $35 \%$ (agree); $17.5 \%$ (neutral / doubtful).

\section{Promoting products on social networks increases operating profit}

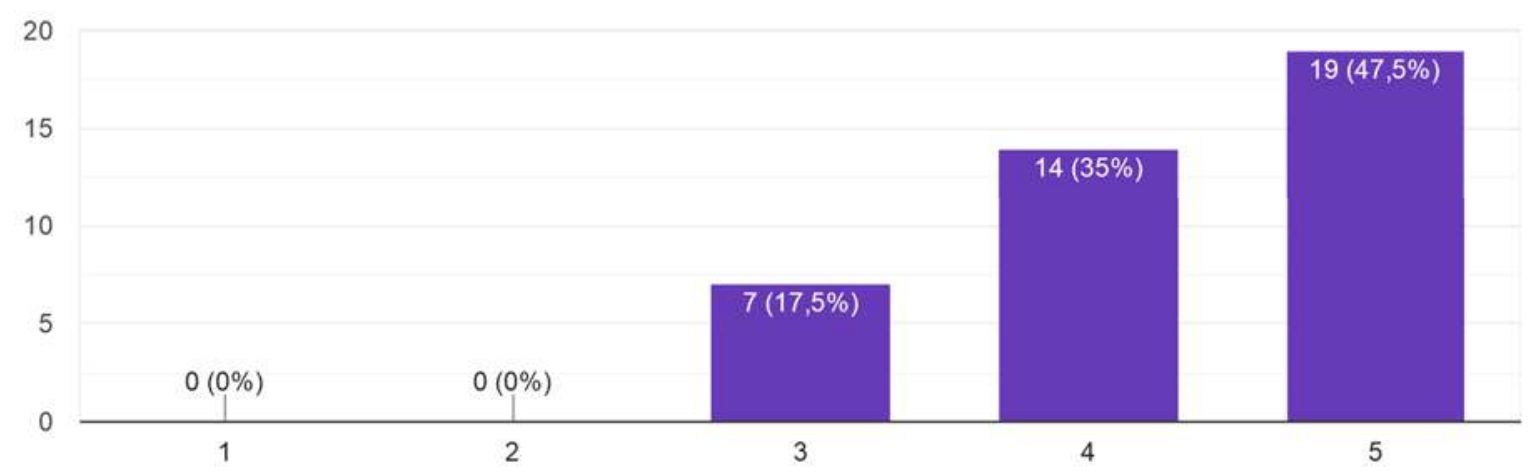

If people buy a product, then they have to look at the product information first on the original social media, otherwise they won't see it. The highest number was 37.5\% who answered "agree", followed by $32.5 \%$ who answered "strongly agree". Because the product must be original on social media, don't fake it. Therefore, the most appropriate answer and the largest number of answers is "agree".

\section{Customers often respond to messages/information about the products I sell on social media}

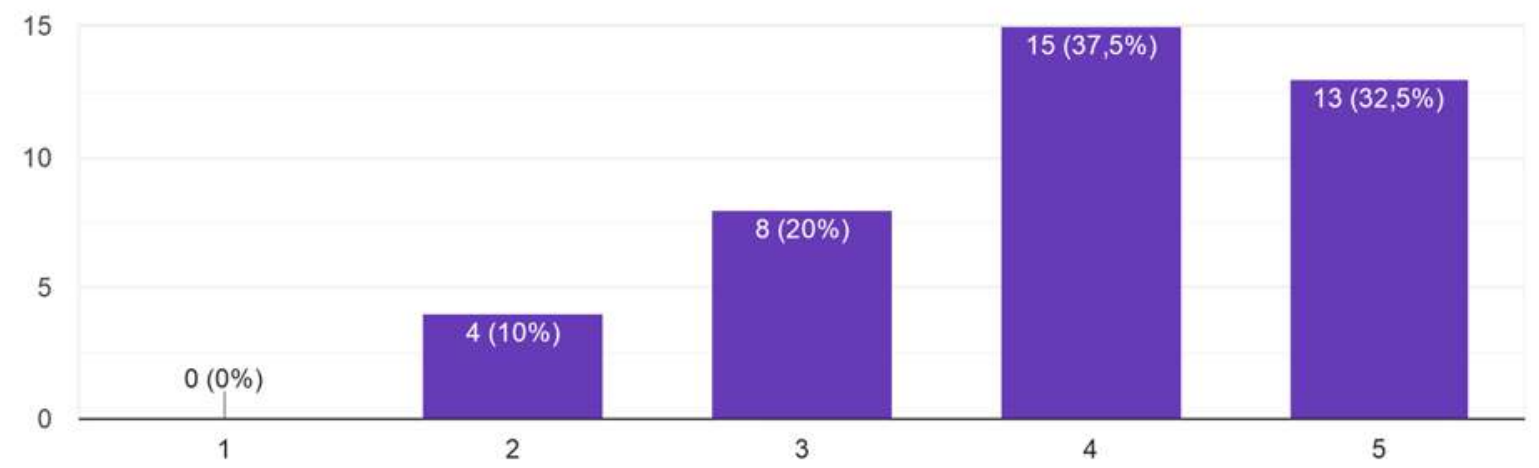

\section{CONCLUSION}

Students are very familiar with social media, they even think that social media is part of their life, and information technology in the form of social media can create new businesses through online sales and optimization of all social media functions, as well as trying all opportunities to promote stores. Online can increase the number of transactions in the future. The social media used by students include Instagram, WhatsApp, Line and Facebook. On Instagram, WhatsApp is the most used media place, and the rest is Line and Facebook. From a detailed description of the results of the analysis and discussion in this study, it can be concluded that the business continuity of millennial MSMEs is positively and significantly influenced by the use of social media, creativity and venture capital. Get free promos and have a wider market share. Therefore, promotion through social media is very effective among students.

As an Integrated Marketing Communication (IMC), social media can provide a competitive advantage for SMEs. At least SMEs can communicate with existing customers and attract new potential customers so that SMEs can survive the competition. Compared to television and print media, students are more interested in promoting through social media (especially Instagram). You can easily use social media for promotions anytime and anywhere. Every day, cellphones are everywhere and always up to date. 
We must start with technological and information innovation and build on a consistent basis. Therefore, SMEs must make full use of technology. It is not only the simplest technology, but also technology capable of producing high value added products. Get free promotions and a wider market share. Therefore, promotion through social media is very effective among students. The technology used to realize the E-UMKM concept includes several stages, namely the stage of network creation, the stage of socialization and data collection and certification of UMKM products, the stage of data input of certified MSME products to the network, and the delivery stage. In addition, during the COVID-19 pandemic, social media platforms played an important role in marketing MSME products during the COVID-19 pandemic. Some UMKM participants have used social media for marketing, but it is still small and poorly organized. Utilizing social media as an effective means of supporting MSME operations during the COVID-19 pandemic, because UMKM participants can still carry out their business activities by complying with and implementing health protocols. It is not impossible, if used optimally, social media can create a brand image and satisfaction for MSME players which have an impact on loyalty and MSMEs can keep up with the rate of information development. Thus, UKM is no longer considered a marginal business and its existence is neglected. This is because SMEs are economic actors who have a strategic role in the economy.

In a business environment, the internet has a transparent influence, thus giving birth to a new paradigm in running a business in the form of digital marketing or internet marketing. The term Internetization refers to the process by which companies carry out business activities (e-commerce or e-commerce) electronically, in particular by using the Internet as a medium, market and supporting infrastructure. In the process of absorbing social media, craft MSMEs are classified as low complexity because the social media used is only in the form of simple product launches designed to support marketing activities. The low ability of MSMEs in adopting social media has led to the importance of supplier involvement in the adoption process. This characteristic leads to the use of IT in product design and manufacturing. The production process becomes unnecessary. Therefore, the use of social media is more intended to support marketing activities, and the direction of its development is to use the internet as a means of commercial transactions in the form of electronic catalogs and e-commerce.

\section{REFERENCES}

Prawiro, M. (2020, Juli 03). Pengertian UMKM: Kriteria, Klasifikasi, Ciri-ciri, dan Contoh UMKM. Retrieved from maxmanroe.com: https://www.maxmanroe.com/vid/bisnis/pengertian-umkm.html

Rustian, R. S., \& Nimda. (2012, Maret 1). Apa itu Sosial Media. Retrieved from unpas.ac.id: http://www.unpas.ac.id/apa-itu-sosial-media/

Bayer, J., Schoenebeck, S., Brady, E., \& Ellison, N. (2018). Facebook in Context(s): measuring Emotional Responses Across Time and Space. New Media \& Society, 20(3), 1047-1067. Doi: $10.1177 / 1461444816681522$

Barnier, B. (2020, Maret 20). Gross National Product (GNP). Retrieved from investopedia.com: https://www.investopedia.com/terms/g/gnp.asp

Bocconcelli, R., Cioppi, M., \& Pagano, A. (2017). Social Media as a Resource in SMEs' Sales Process. Journal of Business \& Industrial Marketing, 32(5), 693-709. doi:10.1108/JBIM-11-2014-0244

Admin. (2012, Januari 4). Pengertian dan Jenis Metode Deskriptif. Retrieved from idtesis.com: https://idtesis.com/metode-deskriptif/

Ramadhani, N. (2020, Januari 21). Ini Penjelasan Lengkap Seputar Gross Domestic Product (GDP). Retrieved from akseleran.co.id: https:/www.akseleran.co.id/blog/gdp-adalah/

Shemi, A. P., \& Procter, C. (2018, Juni 18). E-commerce and Entrepreneurship in SMEs: Case of myBot. Journal of Small Business and Enterprise Development, 501-520. doi:10.1108/JSBED-03-20170088 
Indonesia, L. P. (2015). Profil Bisnis Usaha Mikro, Kecil dan Menengah (UMKM). Jakarta: LPPI.

Putra. (2019, November 21). PENGERTIAN UMKM: Ciri, Jenis, Kriteria \& Contoh UMKM-UKM Indonesia. Retrieved from salamadian.com: https://salamadian.com/umkm-ukm-indonesia/

Anjarwati, J. (2020, Februari 2). Media Sosial: Pengertian, Jenis, Fungsi, dan Contoh. Retrieved from tekno.foresteract.com: https://tekno.foresteract.com/media-sosial/2/

Purbohastuti, A. W. (2017). EFEKTIVITAS MEDIA SOSIAL SEBAGAI MEDIA PROMOSI. Tirtayasa EKONOMIKA, 12(2), 212-231.

Pratama, E. M., \& Kornitasari, Y. (2018). IDENTIFIKASI PERAN MODAL SOSIAL DALAM PENGEMBANGAN UMKM BATIK (STUDI PADA UMKM BATIK BANYUWANGI). JURUSAN ILMU EKONOMI, 1-11.

Tanti, G. A., \& Dewi, P. E. (2020). Pengaruh Pemanfaatan Media Sosial, Kreativitas dan Modal Usaha Terhadap Keberlanjutan Bisnis UMKM Milenial di Kecamatan Buleleng. JIMAT (Jurnal Ilmiah Mahasiswa Akuntansi), 320-330. doi: 10.23887/jimat.v11i2.25441

Azhari, T. Z., Cahyaningrum, I., Esfandiar, W. N., \& Nuryaningrum, N. (2020, April 10). PEMANFAATAN MEDIA SOSIAL DALAM PEMASARAN PRODUK UMK DI KELURAHAN SIDOKUMPUL, KABUPATEN GRESIK. Jurnal Ilmu Komunikasi, 10(1), 17-31.

Marketing Online, 2011, Strategi Pemasaran via Social Media, www.marketing.co.id, diakses 13 Desember 2012

Basry, A., \& Sari, E. M. (2018, November). PENGGUNAAN TEKNOLOGI INFORMASI DAN KOMUNIKASI (TIK) PADA USAHA MIKRO, KECIL DAN MENENGAH (UMKM). Jurnal IKRAITH Informatika, 53-60. Retrieved from https://journals.upi-yai.ac.id/index.php/ikraithinformatika/article/view/266

Maharani, I., Prasetyo, Y. E., \& Amelia, M. N. (2017). E-UMKM: APLIKASI PEMASARAN PRODUK UMKM BERBASIS ANDROID SEBAGAI STRATEGI MENINGKATKAN PEREKONOMIAN INDONESIA. Prosiding SNATI F, 11-16. Retrieved from https://jurnal.umk.ac.id/index.php/SNA/article/view/1238

Cendana, M., \& Permana, S. D. (2019, Juni). PEMANFAATAN SOSIAL MEDIA SEBAGAI STRATEGI PROMOSI BAGI SUSTAINABILITY BISNIS UMKM. Jurnal Penelitian dan Pengabdian kepada Masyarakat, 7(2), 163-169. doi:10.29313/ethos.v7i2.4382

Siswanto, T. (2013, Januari-Juni). OPTIMALISASI SOSIAL MEDIA SEBAGAI MEDIA PEMASARAN USAHA KECIL MENENGAH. Jurnal Liquidity, 2(1), 80-86.

Melani, A. (2018, Januari 30). Ciptakan Solusi Bisnis bagi Generasi Milenial. Retrieved from liputan6.com: https://www.liputan6.com/bisnis/read/3243997/ciptakan-solusi-bisnis-bagi-generasimilenial

Proxsis Grup. (2018). "Mendorong Generasi Milenial Menjadi Pelaku Bisnis". Diakses Pada Tanggal 20 Februari 2020, Dalam https://www. Proxsisgroup.Com/Mendorong-Generasi-Milenial-MenjadiPelaku-Bisnis/

Permana, R. A. (2018, Juli 5). Manfaat Media Sosial yang Harus Kamu Ketahui! Retrieved from kompasiana.com:

https://www.kompasiana.com/rioagungpermana4748/5b3e3a16ab12ae58ce2f3632/manfaat-mediasosial-yang-harus-kamu-ketahui

Republika. (2016, Desember 26). Mengenal Generasi Millennial. Retrieved from republika.co.id: https://republika.co.id/berita/ois64613/mengenal-generasi-millennial 
Wijayanti, S. (2020, Juni 27). 10 Ciri Dasar Generasi Millennial, Kamu Termasuk Gak Nih? Retrieved from idntimes.com: https://www.idntimes.com/life/inspiration/sinta-wijayanti-d/10-ciri-dasargenerasi-millennial-c1c2/10

K, M. G. (2020, Januari 27). Galak di Media Sosial. Retrieved from tribunnews.com: https://makassar.tribunnews.com/2020/01/27/galak-di-media-sosial 